\title{
Outcomes in Traumatic Brain Injury Patients on Preinjury Anticoagulation and Antiplatelet Agents
}

\author{
Sandra Ho, BA, MHS, 4th year medical student \\ Jefferson Medical College \\ Vismay Thakkar, MBBS \\ Thomas Jefferson University \\ Jack Jallo, MD, PhD, FACS \\ Thomas Jefferson University
}

Follow this and additional works at: https://jdc.jefferson.edu/jhnj

\section{Let us know how access to this document benefits you}

\section{Recommended Citation}

Ho, BA, MHS, 4th year medical student, Sandra; Thakkar, MBBS, Vismay; and Jallo, MD, PhD, FACS, Jack (2013) "Outcomes in Traumatic Brain Injury Patients on Preinjury Anticoagulation and Antiplatelet Agents," JHN Journal: Vol. 8 : Iss. 1 , Article 3.

DOI: https://doi.org/10.29046/JHNJ.008.1.002

Available at: https://jdc.jefferson.edu/jhnj/vol8/iss1/3

This Article is brought to you for free and open access by the Jefferson Digital Commons. The Jefferson Digital Commons is a service of Thomas Jefferson University's Center for Teaching and Learning (CTL). The Commons is a showcase for Jefferson books and journals, peer-reviewed scholarly publications, unique historical collections from the University archives, and teaching tools. The Jefferson Digital Commons allows researchers and interested readers anywhere in the world to learn about and keep up to date with Jefferson scholarship. This article has been accepted for inclusion in JHN Journal by an authorized administrator of the Jefferson Digital Commons. For more information, please contact: JeffersonDigitalCommons@jefferson.edu. 


\section{Outcomes in Traumatic Brain Injury Patients on Preinjury Anticoagulation and Antiplatelet Agents}

\author{
Sandra Ho, BA'; MHS; Vismay Thakkar, MBBS ${ }^{2}$; Jack Jallo, MD, PhD, FACS ${ }^{2}$ \\ ${ }^{1}$ Fourth year medical student, Jefferson Medical College, Philadelphia, PA \\ ${ }^{2}$ Department of Neurosurgery, Thomas Jefferson University and \\ Jefferson Hospital for Neuroscience, Philadelphia, Pennsylvania
}

Keywords: Traumatic brain injury, anticoagulation, antiplatelet, hemorrhage

\section{INTRODUCTION}

Traumatic brain injury (TBI) affects an estimated 1.7 million people a year. Around $75 \%$ of these cases are mild. Falls and motor vehicle accidents are among the leading causes for TBI, with falls accounting for $60.7 \%$ of occurrences in populations 65 years or olderl. As the general population continues to expand both in age and in size, the risk of falls will increase. This poses a problem particularly in light of the pervasive use of anticoagulants and antiplatelet agents for this population, both of which increase the bleeding risk.

Anticoagulants and antiplatelet agents are used for a variety of conditions, including deep venous thrombosis, atrial fibrillation, pulmonary embolism and coronary artery disease. They are also given postoperatively for prosthetic heart valves or stent placement. An estimated 597,689 deaths in 2010 were due to cardiovascular disease, with $80 \%$ above the age of 652 . Stroke caused 129,476 deaths. The use of anticoagulants and antiplatelet agents for prevention of cardiovascular and cerebrovascular events is irrefutable, but little literature has touched on its effects on morbidity and
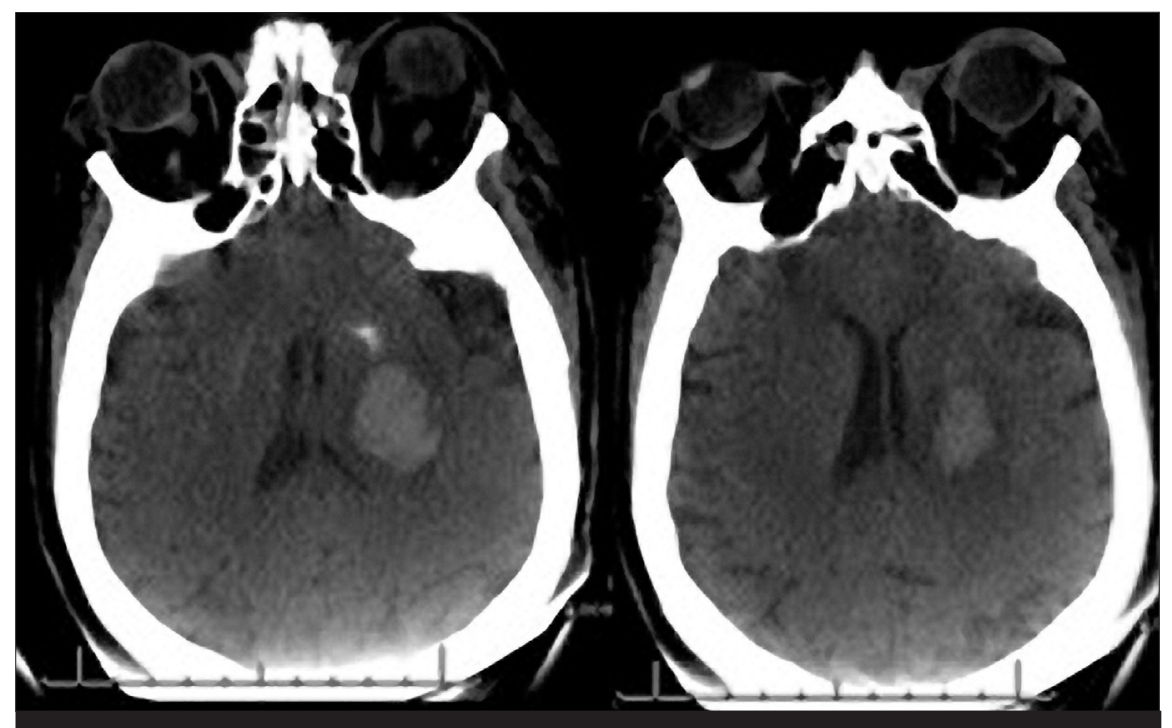

Figure 1

Axial CT scans demonstrating intracerebral hemorrhage. mortality in those with traumatic brain injury. This article summarizes the current literature on the pre-TBI use of anticoagulants and antiplatelet agents and the associated morbidity and mortality.

\section{CASE}

A 68-year-old man with a past medical history of myocardial infarction 6 months ago with stent placement (now on aspirin and plavix), HTN, DM, obesity and 40 pack year smoking complained of an intense headache immediately prior to falling while getting up to go to the bathroom. After the fall, his wife called the paramedics. Shortly after arriving in the emergency department, he became unresponsive and was emergently intubated. CT scan showed ICH (Figure 1). His ICH score upon admission was 4 . His coagulation profile was normal. His platelets were decreased at $110,000 / \mathrm{uL}$.

\section{DISCUSSION}

A large percentage of the population sustaining traumatic brain injury due to falls are also those that are likely to be on chronic antiplatelet or anticoagulation therapy. The increased risk of bleeding with these agents after TBI then becomes worrisome, as increased morbidity and mortality has been shown to occur with any volume of bleeding, with larger volume hemorrhages having the worst prognosis. ${ }^{7,8} \mathrm{~A}$ small number of papers to date have looked at warfarin, aspirin or clopidogrel use in mild TBI patients and mortality. These studies are summarized below and in Table 1 .

\section{Warfarin}

Warfarin is a vitamin K antagonist, and works by inhibiting the enzyme vitamin $\mathrm{K}$ epoxide reductase, which is responsible for carboxylating a glutamic acid residue. This is necessary for calcium binding, allowing connection to phospholipids surfaces to promote clotting. 
Table 1. Summary Of Studies On The Effects Of Anticoagulation Or Antiplatelet Therapy In Patients With Traumatic Brain Injury

\begin{tabular}{|c|c|c|c|c|}
\hline Study & Therapy & $\begin{array}{l}\text { Number of } \\
\text { Subjects }\end{array}$ & Mortality & Major findings \\
\hline Wojcik et al., 2001 & Warfarin & 416 & $\begin{array}{l}7.5 \% \text { wafarin } \\
8.2 \% \text { control }\end{array}$ & $\begin{array}{l}\text { No difference between mortality, ICU stay, LOS, } \\
\text { or discharge disposition }\end{array}$ \\
\hline Mina et al., 2002 & $\begin{array}{l}\text { Warfarin } \\
\text { Aspirin } \\
\text { Clopidogrel }\end{array}$ & 19 & $\begin{array}{l}47 \% \text { aspirin } \\
33 \% \text { warfarin } \\
8 \% \text { control }\end{array}$ & Aspirin and warfarin significantly increased mortality \\
\hline Spektor et al., 2003 & Aspirin & 110 & Not recorded & $\begin{array}{l}\text { No increased incidence of ICH in patients treated with } \\
\text { low-dose aspirin }\end{array}$ \\
\hline Lavoie et al., 2004 & Warfarin & 35 & $\begin{array}{l}40 \% \text { warfarin } \\
21 \% \text { control }\end{array}$ & $\begin{array}{l}\text { Higher frequency of isolate head trauma, more severe head inju- } \\
\text { ries and death }\end{array}$ \\
\hline Ohm et al., 2005 & $\begin{array}{l}\text { Aspirin } \\
\text { Clopidogrel }\end{array}$ & 90 & $\begin{array}{l}23 \% \text { antiplatelet } \\
8 \% \text { control }\end{array}$ & Antiplatelet use in patients with ICH increased mortality \\
\hline Jones et al., 2006 & Clopidogrel & 43 & $7 \%$ clopidogrel & Increased morbidity and blood transfusion requirement \\
\hline Franko et al., 2006 & Warfarin & 159 & $\begin{array}{l}23.9 \% \\
4.9 \% \text { control }\end{array}$ & $\begin{array}{l}\text { Mortality with warfarin greater than control } \\
\text { Age a separate predictor of death }\end{array}$ \\
\hline Pieracci et al., 2007 & Warfarin & 1,511 & $\begin{array}{l}21.9 \% \text { warfarin } \\
15.2 \% \text { control }\end{array}$ & $\begin{array}{l}\text { Increased risk of mortality in patients using warfarin } \\
\text { before ICH compared with controls }\end{array}$ \\
\hline Wong et al., 2008 & Clopidogrel & 111 & $\begin{array}{l}14 \% \text { clopidogrel } \\
3 \% \text { asprin }\end{array}$ & Clopidogrel increases long-term disability and mortality \\
\hline Ahmed et al., 2009 & $\begin{array}{l}\text { Warfarin } \\
\text { Aspirin } \\
\text { Clopidogrel } \\
\text { Heparin }\end{array}$ & 29 & $\begin{array}{l}20 \% \text { warfarin } \\
12.5 \% \text { antiplatelet } \\
20.6 \% \text { control }\end{array}$ & No difference in mortality \\
\hline Fortuna et al., 2009 & $\begin{array}{l}\text { Warfarin } \\
\text { Aspirin } \\
\text { Clopidogrel }\end{array}$ & 166 & $\begin{array}{l}6 \% \text { clopidogrel } \\
13 \% \text { aspirin } \\
17 \% \text { warfarin } \\
20 \% \text { controls }\end{array}$ & No difference in mortality \\
\hline Major et al., 2009 & $\begin{array}{l}\text { Aspirin } \\
\text { Clopidogrel }\end{array}$ & 287 & $1.4 \%$ aspirin & Mortality rate of $21 \%$ in patients with ICH on antiplatelet therapy \\
\hline Bachelani et al., 2011 & Aspirin & 84 & Not recorded & Aspirin did not increase risk of ICH progression or poor outcome \\
\hline Bonville 2011 & $\begin{array}{l}\text { Warfarin } \\
\text { Aspirin } \\
\text { Clopidogrel }\end{array}$ & 271 & $\begin{array}{l}12.3 \% \text { aspirin } \\
9.3 \% \text { clopidogrel }\end{array}$ & Warfarin increased mortality, aspirin and clopidogrel did not \\
\hline
\end{tabular}

Warfarin is cleared by the cytochrome $\mathrm{P} 450$ system in the liver and therefore has the potential to interact with a number of drugs. Warfarin is indicated for prophylaxis and treatment of venous thrombosis, pulmonary embolism, atrial fibrillation, post valve replacement, stroke or systemic embolization after myocardial infarction. It is monitored closely with PT and INR due to variable individual responses. Therapeutic levels usually fall between 2-3 for thromboemolism or atrial fibrillation or 2.5-3.5 with mechanical heart valves that are in the mitral position. ${ }^{28}$
Use of warfarin has been associated with increased risk of intracranial hemorrhage, more severe head trauma and increased mortality. ${ }^{12}$ Studies have shown that higher INR levels at admission are associated with hemorrhage progression and subsequent risk of mortality. ${ }^{29-31}$ The risk of mortality in a patient anticoagulated on wafarin with an ICH after head injury ranges in the literature from $16-80 \% .{ }^{13-15}$ Mina et al. found a $33 \%(4 / 12)$ mortality rate in TBI patients taking warfarin prior to injury versus $8 \%$ (3/37) of controls. The severity of the injury, irrespective of anticoagulation use also seemed to impact mortality, with the majority of the deaths occurring in those falling down stairs. ${ }^{10}$ Franko et al. also found a significant increase in mortality in patients that were anticoagulated, $23.9 \%$ versus controls, $4.9 \% .^{19}$ Pieracci et al. demonstrated increased risk of mortality in patients using warfarin before ICH compared with patients who did not. ${ }^{20}$ Only one study looked at the development of ICH after TBI in patients taking warfarin and found that it was increased compared to controls (57.1\% vs. $30.5 \%) .{ }^{21}$ In contrast, there 
have also been studies that have not found an increase in mortality from warfarin use. Ahmed et al. and Fortuna et al. found no correlation between preinjury warfarin use and mortality. ${ }^{22,23}$ Wojcik et al. also found no significant differences between warfarin and the control group with respect to mortality, ICU stay or LOS and discharge disposition. ${ }^{24}$

\section{Aspirin}

Aspirin, also known as acetylsalicylic acid, is a non-steroidal anti-inflammatory agent with antipyretic, anti-inflammatory, analgesic and antiplatelet effects. It works by irreversibly binding and inhibiting cycloxygenase-1 (COX-1) and inhibiting the production of thromboxane A2 (TXA2), which is normally involved in platelet aggregation. The effects of aspirin persist for the lifetime of the platelet (8-12 days).

The USPSTF currently recommends the use of aspirin to decrease the risk of myocardial infarction and stroke in men and women respectively. Aspirin use has been reported to be as high as $61 \%$ in adults $\geq 65$ years old. ${ }^{3}$

One of the earliest papers (1992) looking at aspirin and hemorrhage in patients with head injuries found that aspirin was a risk factor in developing chronic subdural hematomas. ${ }^{9}$ More recent papers have documented the increased risk of death with aspirin therapy in patients with radiographic evidence of intracranial injury. ${ }^{10,11}$ Mina et. al found a statistically significant mortality rate (47\%) in those taking aspirin compared with controls (8\%). ${ }^{10}$ Another study by other authors at the same institution found almost a threefold increase of death in patients taking either aspirin, clopidogrel or combination antiplatelet therapy compared with controls. However, they did not match comorbid conditions between cases and controls, with $71.1 \%$ of cases manifesting three or more conditions, compared with $34.8 \%$ in the control. ${ }^{11}$ The greater number of comorbid conditions may have had an impact on the increased mortality seen in the cases. In contrast, a study by Spektor et. al found no correlation between low-dose aspirin consumption and the frequency or type of intracranial hemorrhage. ${ }^{17}$ Neither did Bonville et. al. ${ }^{21}$ It should be noted that in these studies, aspirin use was either patient-reported or gathered from outpatient pharmacy records. There were no bleeding times or platelet function tests done to confirm the degree of platelet inhibition.
Misclassification of exposure therefore may have occurred, skewing results and potentially explaining why certain studies were unable to see an effect of aspirin on mortality.

\section{Clopidogrel}

Clopidogrel is a thienopyridine, along with Ticlopidine and Prasugrel. Their mechanism of action involves inhibiting the ADP receptor, P2Y12 on platelets. ADP is stored in platelets and released upon platelet activation and promotes further platelet activation. Clopidogrel was first approved by FDA in 1997 after the Clopidogrel versus Aspirin in Patients at Risk of Ischemic Events (CAPRIE) trial in 1996 found that clopidogrel was more effective than aspirin in reducing cardiovascular events. Clopidogrel is currently FDA-approved for use in reducing the risk of heart attack and stroke and PAD. It is also used in conjunction with aspirin in patients with stents to decrease the risk for in-stent thrombosis. $^{4-6}$

Studies looking at clopidogrel use are lacking and to date, there is no consensus as to whether or not preinjury clopidogrel use increases mortality in patients with TBI. A retrospective chart review by Jones et. al did not find a statistically significant difference in mortality between those on clopidogrel and controls, but did find an increased morbidity and requirement for blood transfusions in patients receiving preinjury clopidogrel16. These findings agreed with those of Wong et. al, which found that prior clopidogrel use in TBI increased long-term disability and mortality. ${ }^{18}$

More recent studies have looked at reversing the antiplatelet effects of aspirin and clopidogrel with platelet transfusions in post-TBI patients. ${ }^{25}$ No clear guidelines currently exist for antiplatelet reversal. A metanalysis by Batchelor et al. found no clear benefit with regards to survival in administering platelets to those with antiplatelet-associated $\mathrm{ICH} .{ }^{26}$ Some studies have even found those receiving transfusions may predict worse outcomes than those that did not receive anything. ${ }^{27}$ Recent development of assays to measure the degree of platelet inhibition such as P2Y12 or the Aspirin Response Test may help to establish recommendations for antiplatelet reversal. These assays may also help accurately assess the degree of platelet inhibition and can provide a more solid cause and effect relationship between antiplatelet use and TBI.

\section{CONCLUSION}

Traumatic brain injury is a common cause of death in young individuals, but the incidence of mortality from TBI is also increasing among the elderly. Hemorrhage progression has been associated with poor outcomes and patients on anticoagulation or antiplatelet therapy coming in with TBI need to be closely monitored for the first few days. With a growing portion of the population on anticoagulation and antiplatelet therapy, the risk of hemorrhage progression will increase and so will mortality. Studies have already demonstrated that coagulopathies are associated with an increased risk of mortality that is likely secondary to hemorrhage progression. A consensus however, still has yet to be reached regarding mortality risk and patient reported anticoagulant or antiplatelet use in traumatic brain injury patients. The benefits of stroke or myocardial infarction prevention have to be weighed against the risk of hemorrhage and death in those at increased risk for traumatic brain injury from a variety of causes. Randomized clinical control trials need to be carried out in order to accurately assess the cause and effect relationship between these agents and development of intracranial bleeding, progression of bleeding and mortality. RCT will also help determine the utility of administering FFP or platelets for reversal of coagulopathies and the effects on morbidity.

\section{REFERENCES}

1. Traumatic Brain Injury in the United States: Emergency Department Visits, Hopsitalizations and Deaths 2002-2006. Center for Disease Control and Prevention, National Center for Injury Prevention and Control; 2004. www.cdc.gov/ TraumaticBrainInjury

2. Center for Disease Control and Prevention 2010. Deaths: Final Data for 2010. http://www.cdc.gov/ nchs/data/dvs/deaths_2010_release.pdf

3. Ajani UA, Ford ES, Greenland KJ, Giles WH, Mokdad AH, Aspirin use among U.S. adults: Behavioral Risk Factor Surveillance System. AM J Prev Med 2006;30:74-7.

4. Bertrand ME, Rupprecht H-J, Urban P, Gershlick AH, CLASSICS Investigators. Double-blind study of the safety of clopidogrel with and without a loading dose in combination with aspirin compared with ticlopidine in combination with aspirin after coronary stenting: the Clopidogrel Aspirin Stent International Cooperative Study (CLASSICS). Circulation 2000; 102: 624-9. 
5. Steinhubl SR, Berger PB, Mann JT 3rd, et al. Early and sustained dual oral antiplatelet therapy following percutaneous coronary intervention. A randomized controlled trial. JAMA 2002; 288: 2411-20.

6. Mehta SR, Yusuf S, Peters RJ, et al. Effects of pretreatment with clopidogrel and aspirin followed by long-term therapy in patients undergoing percutaneous coronary intervention: the PCI-CURE study. Lancet 2001.

7. Broderick JP, Brott TG, Duldner JE, Tomsick T, Huster G. Volume of intracerebral hemorrhage. A powerful and easy-to-use predictor of 30-day mortality. Stroke. 1993 Jul;24(7):987-93.

8. Perel P, Roberts I, Bouamra O, Woodford M, Mooney J, Lecky F. Intracranial bleeding in patients with traumatic brain injury: a prognostic study. $B M C$ Emerg Med. 2009 Aug 3;9:15.

9. Reymond MA, Marbet G, Radü EW, Gratzl O. Aspirin as a risk factor for hemorrhage in patients with head injuries. Neurosurg Rev. 1992;15(1):21-5.

10. Mina AA, Knipfer JF, Park DY, Bair HA, Howells GA, Bendick PJ. Intracranial complications of prein jury anticoagulation in trauma patients with head injury. J Trauma. 2002 Oct;53(4):668-72.

11. Ohm C, Mina A, Howells G, Bair H, Bendick P. Effects of antiplatelet agents on outcomes for elderly patients with traumatic intracranial hemorrhage. J Trauma. 2005 Mar;58(3):518-22.

12. Lavoie A, Ratte S, Clas D, et al. Preinjury wafarin use among elderly patients with closed head injuries in a trauma center. J Trauma 2004;56:802-7.

13. Ferrera P, Bartfiled J. Outcomes of anticoagulated trauma patients. Am J Emerg Med. 1999;17:154-156.

14. Mattle H, Kohler S, Huber P, Rohner M, Steinsiepe KF. Anticoagulation-related intracranial extracerebral hemorrhage. J Neurol Neurosurg Psychiatry. 1989;52:829-837.
15. Wintzen AR, Tijssen JGP. Subdural hematoma and oral anticoagulant therapy. Arch Neurol. 1982;39:69-72.

16. Jones K, Sharp C, Mangram AJ, Dunn EL. The effects of preinjury clopidogrel use on older trauma patients with head injuries. Am J Surg. 2006 Dec;192(6):743-5. PubMed PMID: 17161086.

17. Wong DK, Lurie F, Wong LL. The effects of clopidogrel on elderly traumatic brain injured patients. $J$ Trauma. 2008 Dec;65(6):1303-8

18. Spektor S, Agus S, Merkin V, Constantini S Low-dose aspirin prophylaxis and risk of intracranial hemorrhage in patients older than 60 years of age with mild or moderate head injury: a prospective study. J Neurosurg. 2003 Oct;99(4):661-5.

19. Franko J, Kish KJ, O’Connell BG, Subramanian S, Yuschak JV. Advanced age and preinjury warfarin anticoagulation increase the risk of mortality after head trauma. J Trauma 2006;61:107-10

20. Peirraci FM, Eachempati SR, Shou J, Hydo LJ, Barie PS. Use of long-term anticoagulation is associated with traumatic intracranial hemorrhage and subsequent mortality in elderly patients hospitalized after falls: analysis of the New York State Administrative Database. J Trauma 2007;63:519-24.

21. Bonville DJ, Ata A, Jahraus CB, Arnold-Lloyd T, Salem L, Rosati C, Stain SC. Impact of preinjury warfarin and antiplatelet agents on outcomes of trauma patients. Surgery 2011:150:861-8.

22. Ahmed N, Bialowas C, Kuo Y, Zawodniak L. Impact of Preinjury anticoagulation in patients with traumatic brain injury. South Med J 2009;102:476-80.

23. Fortuna GR, Mueller EW, James LE, Shutter LA, Butler KL. The impact of preinjury antiplatelet and anticoagulant pharmacotherapy on outcomes in elderly patients with hemorrhagic brain injury. Surgery 2008;144:598-603; discussion 603-5.
24. Wojick R, Cipolle MD, Seislove E, Wasser TE, Pasquale MD. Preinjury warfarin does not impact outcome in trauma patients. J Trauma 2001;51:114751; discussion 1151-2.

25. Campbell PG, Sen A, Yadla S, Jabbour P, Jallo J. Emergency reversal of antiplatelet agents in patients presenting with an intracranial hemorrhage: a clinical review. World Neurosurg. 2010 Aug-Sep;74(23):279-85.

26. Batchelor JS, Grayson A. A meta-analysis to determine the effect on survival of platelet transfusions in patients with either spontaneous or traumatic antiplatelet medication-associated intracranial haemorrhage. BMJ Open. 2012 Apr 5;2(2):e000588.

27. Washington CW, Schuerer DJ, Grubb RL Jr. Platelet transfusion: an unnecessary risk for mild traumatic brain injury patients on antiplatelet therapy. J Trauma. 2011 Aug;71(2):358-63.

28. Goldsmith I, Turpie AG, Lip GY. Valvar heart disease and prosthetic heart valves. BMJ. 2002 Nov 23;325(7374):1228-31. Review

29. Stein SC< Young GS, Talucci, RC, Greenbaum $\mathrm{BH}$, Ross SE. Delayed brain injury after head trauma: significance of coagulopathy. Neurosurger 1992;30:160-165

30. Oertel M, Kelly DF, McArthur D, et al. Progressive hemorrhage after head trama: predictors and consequences of the evolving injury. J Neurosurg. 2002;96:109-116.

31. White CL, Griffith S, Caron JL. Early Progression of Traumatic Cerebral Contusions: characterization and risk factors. J Trauma. 2009;67:508-515.

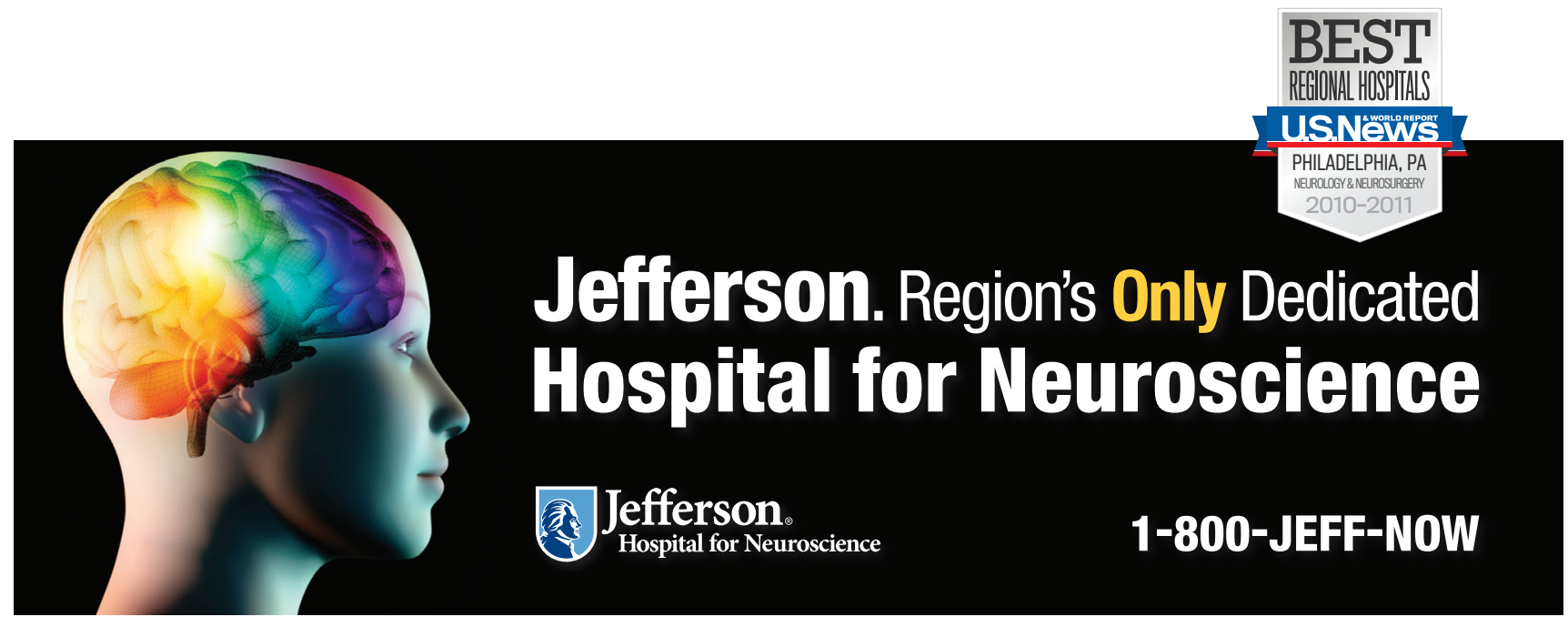

